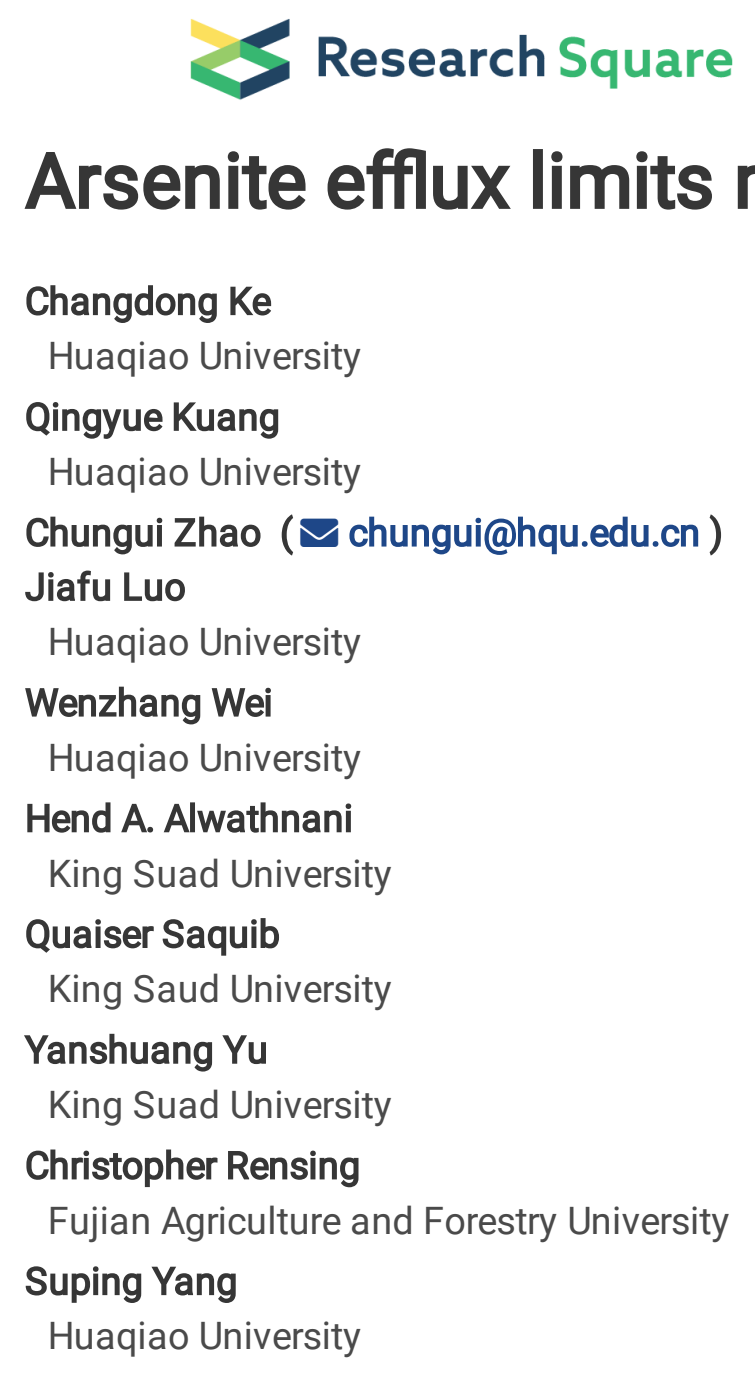

\author{
Changdong Ke \\ Huaqiao University \\ Qingyue Kuang \\ Huaqiao University \\ Chungui Zhao ( $\nabla$ chungui@hqu.edu.cn ) \\ Jiafu Luo \\ Huaqiao University \\ Wenzhang Wei \\ Huaqiao University \\ Hend A. Alwathnani \\ King Suad University \\ Quaiser Saquib \\ King Saud University \\ Yanshuang Yu \\ King Suad University \\ Christopher Rensing \\ Fujian Agriculture and Forestry University

\section{Suping Yang} \\ Huaqiao University
}

\title{
Arsenite efflux limits microbial arsenic volatilization
}

\section{Research article}

Keywords: Arsenic, As efflux transporter, As methylation, Rhodopseudomonas palustris

Posted Date: July 4th, 2019

DOI: https://doi.org/10.21203/rs.2.10508/v1

License: (c) (i) This work is licensed under a Creative Commons Attribution 4.0 International License. Read Full License 


\section{Abstract}

Background: Arsenic (As) methylation is regarded as a potential way to volatize and thereby remove As from the environment. However, most microorganisms conducting As methylation display low As volatilization efficiency as As methylation is limited by As efflux transporters as both processes compete for arsenite [As(III)]. In the study, we deleted arsB and acr3 from Rhodopseudomonas palustris CGA009, a good model organism for studying As detoxification, and further investigated the effect of As(III) efflux transporters on As methylation. Results: Two mutants were obtained by gene deletion. Compared to the growth inhibition rate (IC50) $[1.57 \pm 0.11 \mathrm{mmol} / \mathrm{L} \mathrm{As}$ (III) and $2.67 \pm 0.04 \mathrm{mmol} / \mathrm{L}$ arsenate $[\mathrm{As}(\mathrm{V})]$ of wildtype $\mathrm{R}$. palustris CGA009, the $\mathrm{As}(\mathrm{III})$ and $\mathrm{As}(\mathrm{V})$ resistance of the mutants decreased, and IC50 value of the R. palustris CGA009 $\Delta$ arsB mutant was $1.47 \pm 0.02 \mathrm{mmol} / \mathrm{L} \mathrm{As}(\mathrm{III})$ and $2.12 \pm 0.03 \mathrm{mmol} / \mathrm{L} \mathrm{As}(\mathrm{V})$, respectively, and that of the R. palustris CGA009 $\Delta$ acr3 mutant was $1.21 \pm 0.07 \mathrm{mmol} / \mathrm{L}$ $\mathrm{As}(\mathrm{III})$ and $1.76 \pm 0.12 \mathrm{mmol} / \mathrm{L} \mathrm{As}(\mathrm{V})$, respectively. The As volatilization rate of R. palustris CGA009 $\Delta$ arsB and R. palustris CGA009 $\Delta$ acr3 was 7.36 and 10.46 times higher than that of the R. palustris CGA009 at $100.0 \mu \mathrm{mol} / \mathrm{L}$ As(III) when incubated for $12 \mathrm{~h}$, respectively, and 7.21 and 10.30 times higher than that of the R. palustris CGA009 when incubated with $25.0 \mathrm{~mol} / \mathrm{L} \mathrm{As}(\mathrm{V})$, respectively. At $25.0 \mathrm{~mol} / \mathrm{L} \mathrm{As}(\mathrm{III})$, low doses of methylarsonate [MAs(V)] and dimethylarsonate [DMAs $(\mathrm{V})]$ were detected in both the wild type and in the deletion mutant strains. In addition, the content of $\mathrm{As}$ (III) in the medium changed significantly with the order being R. palustris CGA009 > R. palustris CGA009 $\Delta$ arsB > R. palustris CGA009 $\Delta$ acr3, indicating that Acr3 displayed the highest As(III) efflux rate. Conclusion: The results of this study showed that As efflux transporters were shown to be a remarkable intrinsic factor limiting As volatilization efficiency, and As volatilization rate could be significantly improved by deleting genes encoding microbial As efflux transporters. Our study provided an explanation for the often low rate of microbial As methylation and an effective strategy for screening microorganisms with high As volatilization.

\section{Background}

Arsenic (As) is a highly toxic metalloid widely distributed in nature, and is considered to be one of the toxic compounds that affect human health and environmental contamination that are of great concern [ 1]. The transport and transformation of As in the environment are governed by geochemical as well as biological processes, generating an As biogeochemical cycle [2]. Microorganisms play a key role in driving the As biogeological cycle [3]. Microbes have developed multiple strategies to handle arsenic including As resistance (ars) systems, which reduces cytoplasmic arsenate $[\mathrm{As}(\mathrm{V})]$ to arsenite $[\mathrm{As}(\mathrm{III})]$ which is then transported across the cytoplasmic membrane [ 4, 5]; the As(III) oxidation (aio) system, which oxidizes $\mathrm{As}(\mathrm{III})$ to $\mathrm{As}(\mathrm{V})$ [ 4, 6]; the As(V) respiration (arr) system, which respire and reduce $\mathrm{As}(\mathrm{V})$ to $\mathrm{As}(\mathrm{III})$ [ 4, 7]; and the As methylation (arsM) system, which converts inorganic arsenic into methylated As compound [ 8]. These strategies inspired people to employ these As-metabolizing microbes to remove As from contaminated sites, especially As volatilization that is dependent on As methylation. As methylation catalyzed by As(III) S-adenosylmethionine methyltransferase (ArsM) converts highly toxic As(III) into low-toxic pentavalent mono-, di- and trimethylarsenic compounds, and finally forms volatile trimethylarsenic [TMAs(III)] under aerobic conditions [ 8-10]. Numerous investigations have shown evidence of As volatilization in different environments such as landfill, peatland, paddy soil, geothermal sites and sewage treatment sites [8, 11-13]. Therefore, As methylation and subsequent volatilization can be exploited as a potentially effective measure for bioremediation of As contamination.

As methylation is widespread in the natural environment and is a prerequisite for the production of volatile methylarsine gases [14]. Many microbes, both wild type and engineered strains, are able to methylate As and subsequently volatilize As. However, As volatilization, which is dependent on As methylation, is not efficient for most 


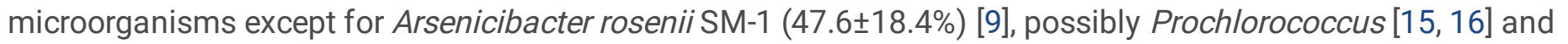
engineered Pseudomonas putida KT2440 (31\%) [17]. On the one hand, some environmental parameters such as organic matter [13, 18], moisture content [ 19], $\mathrm{pH}$ [20], temperature [ 21], Fe(II) and $\mathrm{NH}^{4+}$ [ 22] are able to affect As volatilization efficiency. These parameters might alter the expression level and activity of the gene products of microbial arsMs, which are the genes encoding ArsM, responsible for As methylation, thereby affecting the As methylation rate [20]. On the other hand, internal factors such as the expression of As metabolism genes (such as genes encoding As efflux transporters, arsB, etc.) may also affect microbial As methylation. However, little information is available about the genetic determinants of microorganisms that limit As methylation efficiency. Studies have shown that As methylation and volatilization in soil is a strictly biological process and driven by microbial activity [23-25]. Therefore, it is imperative to explore ways to accelerate the As volatilization rate of microorganisms for remediation of As-contaminated soil or water.

To date, most wild and engineered bacteria containing ars $M$ often contain other genes encoding functions related to As resistance or transformation such as genes encoding As efflux transporters, $\operatorname{ars} A$, $\operatorname{ars} D$, $\operatorname{ars} B$ or $\operatorname{acr} 3$, thus conferring two or more As detoxification mechanisms. For example, Rhodopseudomonas palustris strains (CGA009, TIE-1, HaA2 and BisB5) possess both arsM and genes encoding As efflux transporters (arsB or acr3) [ 26]; Nostoc sp. PCC 7120 possesses both arsM and genes encoding As efflux transporters and/or C-As lyase (Arsl) [27]. As efflux transporters in the cell would reduce the intracellular As content, thereby conferring As resistance to microorganisms $[28,29]$. C-As lyase (ArsI) was shown to demethylate methylarsenite [MAs(III)] to As(III). Since both As(III) and MAs(III) can serve as substrates for ArsM, it is inferred that factors lowering the intracellular As(III) and MAs(III) content inevitably limit As methylation and subsequent As volatilization. More recently, studies have shown that demethylation of As limited the volatilization of As [30,31]. However, it is not known whether other internal factors that reduce intracellular As concentrations would limit microbial As volatilization.

Arsenic efflux is the most ubiquitous detoxification mechanism of microorganisms [ 32]. As efflux transporters reduce intracellular As concentrations by pumping out the corresponding As compounds, thus potentially limiting microbial As methylation and subsequent As volatilization. Previous studies have shown that deletion or inactivation of genes encoding As efflux transporters increased intracellular As accumulation [33]; Arsenicibacter rosenii SM-1 exhibited a higher As volatilization (47.6 $18.4 \%$ ) due to the lack of genes encoding As efflux transporters on its genome [9], and engineered E. coli strain lacking a gene encoding an As efflux pump displayed a higher As volatilization rate ( 10.39\%) [34]. Therefore, As efflux transporters limit the microbial As methylation rate.

R. palustris CGA009, a good model organism for studying As detoxification, has at least three ars operons (ars1, ars2 and ars3), which made it utilize different detoxification strategies under complex environments and the combined ars operons conferred a higher As resistance [26]. Qin et al. [ 8] identified and characterized ArsM from $R$. palustris CGA009 by heterologous expression in As sensitive E. coli AW3110(DE3) ( $\triangle$ arsRBC). Our previous study examined the expression of arsM from $R$. palustris CGA009 at the transcriptional level but conferred a relatively limited ability to volatilize As [26]. Moreover, the arsM derived from R. palustris CGA009 not only endowed the E. coli AW3110(DE3) ( $\triangle$ arsRBC) with As(III) resistance and volatilization rate (>10.39\%), but also ArsM showed higher As volatilization capacity [34]. Curiously, the arsM from R. palustris CGA009 could be expressed and the encoded ArsM was active, but it conferred a relatively limited As volatilization rate for $R$. palustris CGA009. The reason may be that As efflux transporters pump As out of cells, resulting in the decrease of intracellular As concentration, which may restrict the process of As volatilization. 
To test this hypothesis, we deleted $a r s B$ and acr3 from $R$. palustris CGA009, respectively, and obtained two mutant strains to investigate the effect of As efflux transporter on microbial As methylation. This work proposed an explanation for the low As volatilization of microorganisms, which provided an effective strategy for screening microorganisms with highly As volatilization, and laid a good foundation for bioremediation of As-contaminated soil and water.

\section{Results}

\section{Construction and verification of $R$. palustris CGA009 $\triangle$ arsB and $\Delta$ acr3 mutants}

The suicide vector from E. coli WM3064 was transferred into R. palustris CGA009 by conjugation. Single colonies were picked on plates supplemented with $10 \%$ sucrose. These single colonies were considered to be potential mutants and confirmed by PCR. The genomic DNA extracted from the wild strain and from the mutants were used as template for PCR amplification with primers arsBU-F and arsBD-R (Table 1). The amplified fragments of wild strains and mutants were $2500 \mathrm{bp}$ and $2000 \mathrm{bp}$, respectively, which were consistent with the expected results, indicating that $\operatorname{ars} B$ deletion mutants were obtained (Fig. 1a Lane 1-2). Similarly, the PCR-amplified fragment of the wild type strain was 2789 bp for acr3 and that of the acr3 mutants was 1742 bp with primers acr3U-F and acr3D-R (Table 1), respectively (Fig. $1 \mathrm{~b}$ Lane 1-6). We were able to obtain two arsB mutants and six acr3 mutants, and then selected one strain for sequencing, respectively. The sequencing results showed that the deleted gene sequences were identical to that deposited in GenBank Database. The two mutants were named $\Delta$ ars $B$ mutant and $\Delta a c r 3$ mutant, respectively.

\section{Determination of As resistance of mutants}

To compare the ability of the wild type and the mutants to cope with As toxicity, the mutants and wild type were tested for As(III) and As(V) resistance (Fig. 2). Negligible difference was observed between the culture supplemented with $0.1 \mathrm{mmol} / \mathrm{L}$ of $\mathrm{As}(\mathrm{V})$ and the control (no $\mathrm{As}(\mathrm{V})$ ), indicating that a low concentration of $\mathrm{As}(\mathrm{V})$ was not toxic to the wild type and the mutants. The growth rate of bacteria gradually decreased with increasing $\mathrm{As}(\mathrm{III})$ or $\mathrm{As}(\mathrm{V})$ concentrations. When $\mathrm{As}(\mathrm{III})$ and $\mathrm{As}(\mathrm{V})$ concentrations reached $3.0 \mathrm{mmol} / \mathrm{L}$ and $8.0 \mathrm{mmol} / \mathrm{L}$, respectively, the growth of all strains was almost completely inhibited (Fig. S1 of the Supplementary Material). The $/ C_{50}$ of $\mathrm{As}(\mathrm{III})$ and $\mathrm{As}(\mathrm{V})$ for the wild type $R$. palustris CGA009 was $1.57 \pm 0.11$ and $2.67 \pm 0.04 \mathrm{mmol} / \mathrm{L}$, while that of $R$. palustris CGA009 $\Delta$ ars $B$ mutant was $1.47 \pm 0.02$ and $2.12 \pm 0.03 \mathrm{mmol} / \mathrm{L}$, and that of $R$. palustris CGA009 $\Delta$ acr mutant was $1.21 \pm 0.07$ and $1.76 \pm 0.12 \mathrm{mmol} / \mathrm{L}$, respectively (Table S1 of the Supplementary Material). Compared to R. palustris CGA009, the mutants displayed lower resistance to $\mathrm{As}(\mathrm{III})$ and $\mathrm{As}(\mathrm{V})$, and the resistance to $\mathrm{As}(\mathrm{V})$ was significantly higher than that of As(III). These results also indicated that there was a difference in the As efflux activity of ArsB and Acr3, and the As efflux activity of Acr3 was higher.

\section{As volatilization rate by mutants}

To examine the As volatilization rate of the mutants in comparison to the wild type, the difference in total As content before and after bacterial growth was used to assess the As volatilization rate (Fig. 3). After incubation for $12 \mathrm{~h}$ and $24 \mathrm{~h}$ in the presence of $25.0 \mu \mathrm{mol} / \mathrm{L} \mathrm{As}(\mathrm{III})$, the total As content in the medium decreased by $3.91 \%$ and $5.83 \%$ when 
incubated with the $R$. palustris CGA009 $\Delta$ arsB mutant, and that of $R$. palustris CGA009 $\Delta$ acr3 mutant decreased by $5.42 \%$ and $9.19 \%$, respectively; whereas the total As content decreased by only $0.97 \%$ and $0.49 \%$ when incubated with the wild type $R$. palustris CGA009, respectively. When exposed to $100.0 \mu \mathrm{mol} / \mathrm{L} \mathrm{As}(\mathrm{III})$ under the same conditions, the total As content in the medium decreased by $3.58 \%$ and $5.65 \%$ when incubated with the $R$. palustris CGA009 $\Delta$ arsB mutant, and that of $R$. palustris CGA009 $\Delta$ acr3 mutant decreased by $5.10 \%$ and $11.62 \%$, respectively; whereas the total As content decreased by only $0.49 \%$ and $1.54 \%$ with the wild type R. palustris CGA009, respectively. Similarly, when exposed to $\mathrm{As}(\mathrm{V})$, the wild type and the two mutants also exhibited different As volatilization rates. After incubation for $24 \mathrm{~h}$ exposed to $100.0 \mu \mathrm{mol} / \mathrm{L} \mathrm{As}(\mathrm{III})$, the $R$. palustris CGA009 $\Delta$ acr3 mutant showed the highest As volatilization rate with the rate reaching $12.40 \%$ of the total As. It can be concluded that the efflux capacity of Acr3 is greater than that of ArsB, and the presence of both ArsB or Acr3 could significantly limit the As volatilization rate.

\section{Arsenic speciation in mutants}

Both wild type and mutants were exposed to $25.0 \mu \mathrm{mol} / \mathrm{L} \mathrm{As}(\mathrm{III})$ for $24 \mathrm{~h}$, the resulting As species were analyzed by HPLC-ICP-MS (Fig. 4). MAs(V) and DMAs(V) were detected, but their total accumulated concentration did not change significantly, while the As(III) concentration showed a major decrease. The residual As(III) in the medium was wild type $R$. palustris CGA009 > R. palustris CGA009 $\Delta$ arsB > R. palustris CGA009 $\Delta$ acr3, further indicating that the presence of As efflux transporters could significantly limit As volatilization rate.

\section{Discussion}

Arsenic contamination has raised worldwide concern due to the excessive anthropogenic release of As to the environment and its severe toxicity to organisms and ecosystems [1]. Therefore, there is an increasing interest in finding effective bioremediation tools able to remove As from As-contaminated environment. Currently, the concept of "green and sustainable remediation" has been advocated for heavy metal pollution in the world [35]. In view of the fact that bioremediation could better maintain soil structure and ecological balance, bioremediation of As by microorganisms has been advocated because of the microorganism's potential advantages in facilitating economically viable and environmental friendly technologies [36-38]. The final product of As methylation, gaseous trimethylarsine (TMAs(III)), could remove As from contaminated sites by As volatilization, thereby increasing the possibilities for bioremediation of As-contaminated environment $[8,10,34]$. As methylation is widespread in natural environment, and the genes encoding ArsM were shown to be distributed widely in various environments (e.g., paddy soil, groundwater, acid mine drainage and composting manure) [22,39-42] and in every kingdoms of life [43]. However, the majority of microorganisms exhibited a relatively limited ability to volatilize As [25]. Besides environmental factors such as organic matter [13, 18], moisture content [19], pH [20], temperature [ 21], Fe(II) and $\mathrm{NH}^{4+}$ [22], internal factors (such as genes encoding As efflux transporters, arsB, etc.) may also limit As volatilization rate of microorganisms. The As methylation rate not only determines whether As methylation is an important factor in detoxification [44], but also determines the application value of As methylation and subsequent volatilization. Therefore, it is necessary to improve the As methylation efficiency of microorganisms for As contamination remediation.

Arsenic efflux is the most important As detoxification mechanisms of microorganisms. To date, six types of As efflux transporters (ArsB, Acr3, ArsJ, ArsP, MSF1, and ArsK) have been found in various As-resistant bacteria, and each was shown to translocate different types of As compounds out of the cell [32]. arsB and acr3 are both widespread 
genetic determinants encoding As(III) efflux transporters in As-resistant bacteria [ 45]. The MAs(III) efflux permease ArsP was identified in Campylobacter jejuniand shown to confer resistance to the organic arsenicals Rox(III) and MAs(III) but not to inorganic As(III) [ 46]. ArsJ and MSF1 were shown to extrude As(V) [47, 48], and ArsK conferred resistance to As(III), Sb(III), Rox(III) and MAs(III) but did not confer resistance to As(V) or dimethylarsenite [DMAs(III)] [49]. However, it is unclear whether the expression of these As efflux transporters would influence the microbial ArsM-mediated As methylation. Either arsB or acr3 is present in almost every prokaryotic species, and in some cases, both genes are present within a single organism, although no example of the coexistence of the two transporters encoded on the same operon has been reported [45]. ArsB proteins have only been detected in prokaryotes, whereas Acr3 proteins can be found in bacteria, archaea, fungi and some plants [45]. The arsB/ acr3 encoded transporters pump As(III) out of the cell, which reduces the substrate concentration available for ArsM. Therefore, the presence of ArsB/Acr3 limits the As methylation efficiency of microorganisms. In this study, two As efflux genes (arsB/acr3) from $R$. palustris CGA009 were knocked out, respectively. The results showed that the resistance of the two mutants (R. palustris CGA009 $\triangle a r s B$ and $\triangle a c r 3$ ) to $\mathrm{As}(\mathrm{III})$ and $\mathrm{As}(\mathrm{V})$ decreased, but the As volatilization rate increased. The $R$. palustris CGA009 $\triangle a c r 3$ mutant with a high As volatilization rate was obtained with the rate reaching $12.40 \%$ of the total As $(25.0 \mu \mathrm{mol} / \mathrm{L} \mathrm{As}(\mathrm{III}))$. As efflux is a widespread and effective As detoxification pathway for microorganisms compared to As methylation [32], which was one of the possible reasons for the low efficiency of As methylation in $R$. palustris CGA009. These results indicated that As efflux transporters limited the As methylation efficiency of microorganisms. Compared to Arsenicibacter rosenii SM-1 with a higher As volatilization rate (47.6 $\pm 18.4 \%$ ) [9], the $R$. palustris CGA009 $\triangle$ acr3 mutant exhibited a low As volatilization rate, which may indicate other reasons that limit As volatilization. On the one side, there is still a gene encoding ArsB in R. palustris CGA009; on the other side, low concentrations of As in the cells or low catalytic efficiency of ArsM will result in low As volatilization rate. Therefore, in a follow-up study, it may be possible to increase the As uptake by bacteria by knocking in genes such as $g / p F$ encoding the aquaglyceroporin channel GlpF or phosphate transporters, or to obtain higher activity of ArsM by increasing the number of copies of arsM or by directed evolution of ArsM, which may improve the As volatilization efficiency of the microorganism.

Previous studies had shown that ArsM encoded on the genome of $R$. palustris CGA009 displayed a high methylation acitivity [34]; therefore, a series of studies have been conducted with this enzyme, which is considered as a suitable candidate for an applied As methylation process in bioremediation [17, 34, 50, 51]. However, this study and previous studies [26] showed that $R$. palustris CGA009 did not exhibit a significant As volatilization rate with the rate reaching less than $1 \%$ of the total As $(25.0 \mu \mathrm{mol} / \mathrm{L} \mathrm{As}(\mathrm{III}))$. Therefore, microorganisms with a highly active ArsM do not necessarily display a high As methylation rate, which may be due to internal factors (e.g., As efflux transporter) that limit the As volatilization rate. Past series of investigations have revealed As metabolism genes such as As efflux transporter genes or aio (arsenite oxidation) genes were commonly found in As-contaminated environments [41, 5254]. These are all possible intrinsic factors that limit both As methylation and volatilization by lowering the intracellular As(III) content. In later studies, we intend to further investigate the effects of expression of other genes encoding functions related to As metabolism on microbial As methylation, and explore the factors that improve the As volatilization rate.

\section{Conclusions}

We demonstrated the interaction between As efflux transporters and ArsM by constructing mutants in genes encoding As efflux transporters. As efflux transporters were shown to be a remarkable intrinsic factor limiting As volatilization efficiency. The As volatilization efficiency was negatively related to As efflux activity of efflux transporters, and As volatilization rate could be significantly improved by deleting genes encoding microbial As 
efflux transporters. This work identified one of the reasons for the low efficiency of microbial As methylation, which could result in developing an effective strategies for modifying microorganisms to obtain higher As volatilization possibly creating an efficient bioremediation tool able to remove As from the environment.

\section{Materials And Methods}

\section{Strains, plasmid, reagent and culture conditions}

Rhodopseudomonas palustris CGA009 (ATCC BAA-98) was obtained from the American Type Culture Collection (ATCC, USA) for anaerobic culture in modified Ormerod medium at $30^{\circ} \mathrm{C}$ with continuous illumination [55]. Escherichia coli strains were grown aerobically at $37^{\circ} \mathrm{C}$ in Luria-Bertani (LB) medium [56]. E. coli DH5a (Tiangen Biochemical Technology Co., Ltd., Beijing, China) was used for plasmid construction and replication. E. coli WM3064 served as the plasmid donor in conjugation with R.palustris, was a present by the Institute of Hydrobiology, Chinese Academy of Sciences. Plasmid pJQ200SK $\left(\mathrm{Gm}^{\mathrm{R}}\right)$ was purchased from Miaolingbio, Inc. (Hubei, China). As(V) $\left(\mathrm{Na}_{3} \mathrm{AsO}_{4} \cdot 12 \mathrm{H}_{2} \mathrm{O}\right)$ and $\mathrm{As}(\mathrm{III})\left(\mathrm{NaAsO}_{2}\right)$ were obtained from Merck (Darmstadt, Germany). The standard sample of As is $\mathrm{As}(\mathrm{III}), \mathrm{As}(\mathrm{V})$, methylarsonate [MAs(V)] and dimethylarsonate [DMAs(V)] mixed standard solution. The As concentration of each form is $10 \mu \mathrm{g} / \mathrm{L}$, and $\mathrm{As}(\mathrm{V})$ and $\mathrm{As}(\mathrm{III})$ for standard preparation were purchased from Beijing Zhonglian Chemical Reagent Co., Ltd.; MAs(V) and DMAs(V) were purchased from AccuStandard. Inc (New Haven, CT, USA). All other used reagents were purchased from commercial sources, and were of analytical grade or better.

\section{Construction and identification of $R$. palustris mutants}

The arsB/acr3 gene of wild-type $R$. palustris CGA009 was deleted according to a previously described method [57]. The arsB gene (WP_011157811.1) on the ars1 operon was partially deleted, resulting in a frameshift mutation with gene knockout fragments of 500 bp (gene locus No. 2558468-2558967), with primers designed on the 1000 bp upstream and downstream flanking DNA. The acr3 gene (WP_042441211.1) on the ars2 operon was entirely deleted, and primers were designed with $756 \mathrm{bp}$ and $986 \mathrm{bp}$ upstream and downstream flanking DNA, respectively. The primers were designed by Olig 7.0 software (Molecular Biology Insights, Inc., Plymouth, MN, USA) (Table 1) and synthesized by Suzhou Genewiz Biotechnology Co., Ltd. (Suzhou, China). Primer design principles for amplification of upstream and downstream flanking DNA follow overlap extension PCR [58]. The upstream and downstream flanking DNA were amplified by PCR from R. palustris CGA009. All cloning methods, unless otherwise stated, were carried out as performed in Denman et al [56]. The DNA fragment and suicide plasmid pJQ200SK were doubledigested with the corresponding restriction enzymes (Table 1) and were recovered by agarose gel electrophoresis. The gene fragment was ligated with the pJQ200SK plasmid. The suicide plasmid pJQ200SK-arsBUD and pJQ200SK-acr3UD were identified by double enzyme digestion and then transformed into competent $E$. coli WM3064 cells. The recombinant E. coli WM3064 (pJQ200SK-arsBUD) and E. coli WM3064 (pJQ200SK-acr3UD) were screened for gentamicin resistance, verified by double enzyme digestion and sequencing by Shanghai Bioengineering Co., Ltd. (Suzhou, China). The identified suicide plasmids pJQ200SK-arsBUD and pJQ200SK-acr3UD were mobilized from E. coli WM3064 into R. palustris CGA009 by conjugation. Colonies that contained plasmids that had undergone a single recombination and had inserted into the chromosome were identified by growth on modified Ormerod medium containing gentamicin resistance. These colonies were streaked onto modified Ormerod medium plates supplemented with $10 \%$ sucrose to identify strains that had undergone a double recombination to lose the sacB-containing vector. Positive mutants were confirmed by PCR and sequencing by Shanghai Bioengineering Co., Ltd. (Suzhou, China). 


\section{As resistance assays}

R. palustris CGA009 and its mutant strain were anaerobically incubated until reaching an $O D_{660}$ of about 0.4 and inoculated in $4.0 \mathrm{~mL}$ modified Ormerod medium containing different As concentrations. Various concentrations of $\mathrm{As}(\mathrm{III})$ and $\mathrm{As}(\mathrm{V})$ were added with final concentrations ranging from 0.1 to $3.0 \mathrm{mmol} / \mathrm{L}$ and ranging from 0.1 to 8.0 $\mathrm{mmol} / \mathrm{L}$, respectively. Control experiments without As(III) were carried out under the same conditions. Each experiment was repeated in triplicate. Cell growth was estimated by measuring the $O D_{660}$ after incubation anaerobically at $30^{\circ} \mathrm{C}$ and with 2500 lux light for 4 days. The bacterial growth curve was plotted and the concentration $\left(I C_{50}\right)$ at which As inhibited bacterial growth by $50 \%$ was calculated.

\section{As volatilization of $R$. palustris mutants}

The difference in total As content before and after bacterial growth was used to assess the As volatilization of $R$. palustris mutants. $4.0 \mathrm{~mL}$ of cells of the mutant strain and wild type ( $O D_{660}$ about 0.4$)$ was cultured in modified Ormerod medium containing 25.0 and $100.0 \mu \mathrm{mol} / \mathrm{L} \mathrm{As}(\mathrm{III})$ and $\mathrm{As}(\mathrm{V})$, respectively. Control experiments without As were performed under the same conditions. Each experiment was repeated in triplicate. These experiments were performed at $30{ }^{\circ} \mathrm{C}$ and with 2500 lux light for $12 \mathrm{~h}$ and $24 \mathrm{~h}$ and submitted for total As measurement. $1.0 \mathrm{~mL}$ of the sample was digested and referred to the national standard (GB/T5009.11-2014) (http://down.foodmate.net/standard/sort/3/47736.html), and the total As was determined by atomic fluorescence spectroscopy (AFS-8220, Beijing Jitian Instrument Co., Ltd., Beijing, China). This digesting system was provided with a $60 \mathrm{~mA}$ As lamp, $-270 \mathrm{~V}$ high pressures, $300 \mathrm{~mL} / \mathrm{min}$ carrier gas flow, $200 \mathrm{~mL} / \mathrm{min}$ auxiliary gas flow, $200^{\circ} \mathrm{C}$ atomizer temperature, $10 \mathrm{~s}$ sampling time, and $5 \% \mathrm{HCl}$ mobile phase. These measurements were performed at Xiamen Haorun Environmental Protection Technology Co., Ltd. (Fujian, China).

\section{As Speciation Analysis}

$1.0 \mathrm{~mL}$ of the mutant and the wild type cultured for $24 \mathrm{~h}$ were digested with $10 \mathrm{~mL}$ of $1 \%(\mathrm{~V} / \mathrm{V}) \mathrm{HNO}_{3}$ with a microwave digestion apparatus (MASTER 40A, Sineo Microwave Chemistry Technology Co., Ltd, Shanghai, China) for microwave-assisted digestion. The digestion parameters were set as described previously [59]. The digested sample was centrifuged at $4^{\circ} \mathrm{C} 8000 \times \mathrm{g}$ for $5 \mathrm{~min}$ to collect supernatant. The supernatant was filtered through 0.22 $\mu \mathrm{m}$ membrane (Millipore, Bedford, MA, USA), and analyzed by the high-performance liquid chromatography (HPLC) (Agilent 1200ヌAgilentखUSA) coupled with inductively-coupled plasma mass spectrometry (ICP-MS) (Agilent 7700cx》 Agilent囚USA) using previously established instrument parameters [60]. Chromatographic columns were obtained from Hamilton and consisted of a precolumn $(25 \mathrm{~mm} \times 2.3 \mathrm{~mm})$ and a PRP-X100 $10 \mu \mathrm{m}$ anion-exchange column $(250 \mathrm{~mm} \times 4.1 \mathrm{~mm})$. The mobile phase consisted of $10.0 \mathrm{mmol} / \mathrm{L}$ diammonium hydrogen phosphate $\left(\mathrm{NH}_{4} \mathrm{H}_{2} \mathrm{PO}_{4}\right)$ and $10.0 \mathrm{mmol} / \mathrm{L}$ ammonium nitrate $\left(\mathrm{NH}_{4} \mathrm{NO}_{3}\right)$ adjusted to $\mathrm{pH} 9.25$ using nitric acid $\left(\mathrm{NH}_{3} \cdot \mathrm{H}_{2} \mathrm{O}\right)$. As speciation in the samples were identified by retention times to the mixed standards including $\mathrm{As}(\mathrm{III}), \mathrm{As}(\mathrm{V}), \mathrm{MAs}(\mathrm{V})$ and $\mathrm{DMAs}(\mathrm{V})$ whose concentration of As in each form is $10 \mathrm{ug} / \mathrm{L}$. The As was quantified by external calibration curves with peak areas. these works were performed at the Institute of Urban Environment, Chinese Academy of Sciences (Fujian, China).

\section{Abbreviations}


As: Arsenic; As(III): Arsenite; As(V): Arsenate; MAs(V): Methylarsonate; DMAs(V): Dimethylarsonate; TMAs(III):

Trimethylarsenic; ArsM: Arsenite S-adenosylmethionine methyltransferase; Arsl: C-As lyase.

\section{Declarations}

\section{Acknowledgments}

The authors are grateful for the facilities provided by Xiamen Haorun Environmental Protection Technology Co., Ltd. (Fujian, China) and Institute of Urban Environment, Chinese Academy of Sciences (Fujian, China).

\section{Funding}

This work was funded by National Marine Public Industry Research (No. 201505026), by Natural Science Foundation of Fujian Province (No. 2018J01049), by Subsidized Project for Cultivating Postgraduates Innovative Ability in Scientific Research of Huaqiao University. Authors would like to thank Twasol Research Excellence Program (TRE Program), King Saud University, Riyadh, Saudi Arabia for support.

\section{Availability of data and materials}

The gene sequences are available in the NCBI database. All data generated or analyzed during this study are included in this published article and its additional files.

\section{Authors' contributions}

CDK wrote the manuscript and conducted the experiment. CGZ and SUP designed the experiments. QYK, JFL and WZW participated in some experiments. HAA, QS, YSY and CR participated in the initial draft and the revision of the manuscript. All authors read and approved the final manuscript.

\section{Ethics approval and consent to participate}

Not applicable.

\section{Competing interests}

The authors declare that they have no competing interests.

\section{References}

1. Yamauchi H, Takata A. Past and current arsenic poisonings. In: Yamauchi H, Sun G, editors. Arsenic contamination in Asia. Current topics in environmental health and preventive medicine. Springer, Singapore; 2019. p. $1-11$.

2. Chatterjee S, Moogoui R, Gupta DK. Arsenic: source, occurrence, cycle, and detection. In: Gupta DK, Chatterjee S, editors. Arsenic contamination in the environment. Springer, Cham; 2017. p. 13-35. 
3. Liu Z, Rensing C, Rosen BP. Resistance pathways for metalloids and toxic metals. In: Culotta V, Scott RA, editors. Metals in cells. Wiley \& Sons, Hoboken; 2014. p. 429-442.

4. Oremland RS, Stolz JF. The ecology of arsenic. Science.2003; 300(5621):939.

5. Oremland RS, Stolz JF. Arsenic, microbes and contaminated aquifers. Trends Microbiol. 2005; 13(2):45-49.

6. Lett M-C, Muller D, Lièvremont D, Silver S, Santini J. Unified nomenclature for genes involved in prokaryotic aerobic arsenite oxidation. J Bacteriol. 2012; 194(2):207.

7. Malasarn D, Saltikov CW, Campbell KM, Santini JM, Hering JG, Newman DK. arrA is a reliable marker for As(V) respiration. Science. 2004; 306(5695):455.

8. Qin J, Rosen BP, Zhang Y, Wang GJ, Franke S, Rensing C. Arsenic detoxification and evolution of trimethylarsine gas by a microbial arsenite S-adenosylmethionine methyltransferase. Proc Natl Acad Sci U S A. 2006; 103(7):20752080.

9. Huang K, Chen C, Zhang J, Tang Z, Shen QR, Rosen BP, Zhao FJ. Efficient arsenic methylation and volatilization mediated by a novel bacterium from an arsenic-contaminated paddy soil. Environ Sci Technol. 2016; 50(12):63896396.

10. Soares Guimaraes LH, Segura FR, Tonani L, von-Zeska-Kress MR, Rodrigues JL, Calixto LA, Silva FF, Batista BL. Arsenic volatilization by Aspergillus sp. and Penicillium sp. isolated from rice rhizosphere as a promising eco-safe tool for arsenic mitigation. J Environ Manage.2019; 237:170-179.

11. Pinel-Raffaitin P, Le Hecho I, Amouroux D, Potin-Gautier M. Distribution and fate of inorganic and organic arsenic species in landfill leachates and biogases. Environ Sci Technol.2007; 41(13):4536-4541.

12. Mestrot A, Feldmann J, Krupp EM, Hossain MS, Roman-Ross G, Meharg AA. Field fluxes and speciation of arsines emanating from soils. Environ Sci Technol.2011; 45(5):1798-1804.

13. Huang H, Jia Y, Sun GX, Zhu YG. Arsenic speciation and volatilization from flooded paddy soils amended with different organic matters. Environ Sci Technol.2012; 46(4):2163-2168.

14. Mestrot A, Planer-Friedrich B, Feldmann J. Biovolatilisation: a poorly studied pathway of the arsenic biogeochemical cycle. Environ Sci-Process Impacts.2013; 15(9):1639-1651.

15. Giovannoni SJ, Halsey KH, Saw J, Muslin O, Suffridge CP, Sun J, Lee C-P, Moore ER, Temperton B, Noell SE. A parasitic arsenic cycle that shuttles energy from phytoplankton to heterotrophic bacterioplankton. mBio.2019; 10(2):e00246-00219.

16. Saunders JK, Rocap G. Genomic potential for arsenic efflux and methylation varies among global Prochlorococcus populations. ISME J. 2015; 10:197.

17. Chen J, Sun GX, Wang XX, de Lorenzo V, Rosen BP, Zhu YG. Volatilization of arsenic from polluted soil by Pseudomonas putida engineered for expression of the arsM arsenic(III) S-adenosine methyltransferase gene. Environ Sci Technol.2014; 48(17):10337-10344. 
18. Yang YP, Zhang HM, Yuan HY, Duan GL, Jin DC, Zhao FJ, Zhu YG. Microbe mediated arsenic release from iron minerals and arsenic methylation in rhizosphere controls arsenic fate in soil-rice system after straw incorporation. Environ Pollut.2018; 236:598-608.

19. Shimizu M, Arai Y, Sparks DL. Multiscale assessment of methylarsenic reactivity in soil. 2. distribution and speciation in soil. Environ Sci Technol.2011; 45(10):4300-4306.

20. Zhao FJ, Harris E, Yan J, Ma JC, Wu LY, Liu WJ, McGrath SP, Zhou JZ, Zhu YG. Arsenic methylation in soils and its relationship with microbial arsM abundance and diversity, and As speciation in rice. Environ Sci Technol. 2013; 47(13):7147-7154.

21. Huang K, Chen C, Shen QR, Rosen BP, Zhao FJ. Genetically engineering Bacillus subtilis with a heat-resistant arsenite methyltransferase for bioremediation of arsenic-contaminated organic waste. Appl Environ Microbiol. 2015; 81(19):6718-6724.

22. Wang Y, Li P, Jiang Z, Liu H, Wei D, Wang H, Wang Y. Diversity and abundance of arsenic methylating microorganisms in high arsenic groundwater from Hetao Plain of Inner Mongolia, China. Ecotoxicol. 2018; 27(8):1047-1057.

23. Turpeinen R, Pantsar-Kallio M, Kairesalo T. Role of microbes in controlling the speciation of arsenic and production of arsines in contaminated soils. Sci Total Environ. 2002; 285(1-3):133-145.

24. Zheng RL, Sun GX, Zhu YG. Effects of microbial processes on the fate of arsenic in paddy soil. Chin Sci Bull.2013; 58(2):186-193.

25. Wang PP, Sun GX, Jia Y, Meharg AA, Zhu YG. A review on completing arsenic biogeochemical cycle: Microbial volatilization of arsines in environment. J Environ Sci. 2014; 26(2):371-381.

26. Zhao CG, Zhang Y, Chan ZH, Chen SC, Yang SP. Insights into arsenic multi-operons expression and resistance mechanisms in Rhodopseudomonas palustris CGA009. Front Microbiol. 2015; 6:8.

27. Yan Y, Ye J, Xue XM, Zhu YG. Arsenic demethylation by a C·As lyase in cyanobacterium Nostoc sp. PCC 7120. Environ Sci Technol. 2015; 49(24):14350-14358.

28. Meng YL, Liu Z, Rosen BP. As(III) and Sb(III) uptake by GlpF and efflux by ArsB in Escherichia coli. J Biol Chem 2004, 279(18):18334-18341.

29. Aaltonen EKJ, Silow M. Transmembrane topology of the Acr3 family arsenite transporter from Bacillus subtilis. Biochim Biophys Acta. 2008; 1778(4):963-973.

30. Su SM, Zeng XB, Feng QF, Bai LY, Zhang LL, Jiang S, Li AG, Duan R, Wang XR, Wu CX, Wang YN. Demethylation of arsenic limits its volatilization in fungi. Environ Pollut. 2015; 204:141-144.

31. Yan Y, Xue XM, Guo YQ, Zhu YG, Ye J. Co-expression of cyanobacterial genes for arsenic methylation and demethylation in Escherichia coli offers insights into arsenic resistance. Front Microbiol.2017; 8:60.

32. Garbinski LD, Rosen BP, Chen J. Pathways of arsenic uptake and efflux. Environ Int. 2019; 126:585-597. 
33. Sousa T, Branco R, Piedade AP, Morais PV. Hyper accumulation of arsenic in mutants of Ochrobactrum tritici silenced for arsenite efflux pumps. PloS One.2015; 10(7):e0131317.

34. Ke CD, Xiong H, Zhao CG, Zhang ZG, Zhao XL, Rensing C, Zhang GY, Yang SP. Expression and purification of an ArsM-elastin-like polypeptide fusion and its enzymatic properties. Appl Microbiol Biotech.2019; 103(6):2809-2820.

35. Bardos P. Progress in sustainable remediation. Bioremediat J.2014; 25(1):23-32.

36. Plewniak F, Crognale S, Rossetti S, Bertin PN. A genomic outlook on bioremediation: The case of arsenic removal. Front Microbio. 2018; 9:8.

37. Alam R, McPhedran K. Applications of biological sulfate reduction for remediation of arsenic - A review. Chemosphere.2019; 222:932-944.

38. Ke CD, Zhao CG, Rensing C, Yang SP, Zhang Y. Characterization of recombinant E-coli expressing arsR from Rhodopseudomonas palustris CGA009 that displays highly selective arsenic adsorption. Appl Microbiol Biotech.2018; 102(14):6247-6255.

39. Zhang SY, Zhao FJ, Sun GX, Su JQ, Yang XR, Li H, Zhu YG. Diversity and abundance of arsenic biotransformation genes in paddy soils from southern China. Environ Sci Technol. 2015; 49(7):4138-4146.

40. Zhang SY, Williams PN, Luo J, Zhu YG. Microbial mediated arsenic biotransformation in wetlands. Front Environ Sci Eng. 2016; 11(1):1.

41. Desoeuvre A, Casiot C, Héry M. Diversity and distribution of arsenic-related genes along a pollution gradient in a river affected by acid mine drainage. Microbial Ecol.2016, 71(3):672-685.

42. Zhai WW, Wong MT, Luo F, Hashmi MZ, Liu XM, Edwards EA, Tang XJ, Xu JM. Arsenic methylation and its relationship to abundance and diversity of arsM genes in composting manure. Sci Rep. 2017; 7:11.

43. Chen SC, Sun GX, Rosen BP, Zhang SY, Deng Y, Zhu BK, Rensing C, Zhu YG. Recurrent horizontal transfer of arsenite methyltransferase genes facilitated adaptation of life to arsenic. Sci Rep. 2017; 7(1):7741.

44. Rahman MA, Hassler C. Is arsenic biotransformation a detoxification mechanism for microorganisms? Aquat Toxicol. 2014; 146:212-219.

45. Ben Fekih I, Zhang C, Li YP, Zhao Y, Alwathnani HA, Saquib Q, Rensing C, Cervantes C. Distribution of arsenic resistance genes in prokaryotes. Fron microbiol.2018; 9:2473-2473.

46. Chen J, Madegowda M, Bhattacharjee H, Rosen BP. ArsP: a methylarsenite efflux permease. Mol Microbiol. 2015; 98(4):625-635.

47. Chen J, Yoshinaga M, Garbinski LD, Rosen BP. Synergistic interaction of glyceraldehydes-3-phosphate dehydrogenase and ArsJ, a novel organoarsenical efflux permease, confers arsenate resistance. Mol Microbiol. 2016; 100(6):945-953.

48. Wu SJ, Wang LR, Gan R, Tong T, Bian H, Li ZQ, Du SM, Deng ZX, Chen S. Signature arsenic detoxification pathways in Halomonas sp Strain GFAJ-1. Mbio. 2018; 9(3):9. 
49. Shi K, Li C, Rensing C, Dai X, Fan X, Wang G. Efflux transporter ArsK is responsible for bacterial resistance to arsenite, antimonite, trivalent roxarsone, and methylarsenite. Appl Environ Microbiol. 2018, 84(24):e01842-01818.

50. Yuan CG, Lu XF, Qin J, Rosen BP, Le XC. Volatile arsenic species released from Escherichia coli expressing the AsIII S-adenosylmethionine methyltransferase gene. Environ Sci Technol. 2008; 42(9):3201-3206.

51. Liu S, Zhang F, Chen J, Sun GX. Arsenic removal from contaminated soil via biovolatilization by genetically engineered bacteria under laboratory conditions. J Environ Sci.2011; 23(9):1544-1550.

52. Xiao KQ, Li LG, Ma LP, Zhang SY, Bao P, Zhang T, Zhu YG. Metagenomic analysis revealed highly diverse microbial arsenic metabolism genes in paddy soils with low-arsenic contents. Environ Pollut. 2016; 211:1-8.

53. Chang JS, Ren X, Kim KW. Biogeochemical cyclic activity of bacterial arsB in arsenic-contaminated mines. J Environ Sci. 2008; 20(11):1348-1355.

54. Achour AR, Bauda P, Billard P. Diversity of arsenite transporter genes from arsenic-resistant soil bacteria. Res Microbiol. 2007; 158(2):128-137.

55. Zhao L, Zhao CG, Han DX, Yang SP, Chen SH, Yu CP. Anaerobic utilization of phenanthrene by Rhodopseudomonas palustris. Biotechnol Lett. 2011; 33(11):2135-2140.

56. Denman AM. Molecular cloning: a laboratory manual. Immunology.1983; 49(2):411.

57. Rey FE, Oda Y, Harwood CS. Regulation of uptake hydrogenase and effects of hydrogen utilization on gene expression in Rhodopseudomonas palustris. J Bacteriol.2006; 188(17):6143.

58. Bryksin AV, Matsumura I. Overlap extension PCR cloning: a simple and reliable way to create recombinant plasmids. BioTechniques.2010; 48(6):463-465.

59. Zhu YG, Sun GX, Lei M, Teng M, Liu YX, Chen NC, Wang LH, Carey AM, Deacon C, Raab A, Meharg AA, Williams $\mathrm{PN}$. High percentage inorganic arsenic content of mining impacted and nonimpacted Chinese rice. Environ Sci Technol.2008; 42(13):5008-5013.

60. Yin XX, Chen J, Qin J, Sun GX, Rosen BP, Zhu YG. Biotransformation and volatilization of arsenic by three photosynthetic cyanobacteria. Plant Physiol. 2011; 156(3):1631-1638.

\section{Table 1}

Table 1 List of primers for this study 


\begin{tabular}{|c|c|c|c|c|}
\hline $\begin{array}{l}\text { Gene } \\
\text { name }\end{array}$ & $\begin{array}{l}\text { Gene } \\
\text { Siz } \\
\text { e(bp) }\end{array}$ & Primer sequence $\left(5^{\prime} \rightarrow 3^{\prime}\right)$ & $\begin{array}{l}\text { Enzyme } \\
\text { site }\end{array}$ & 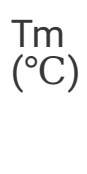 \\
\hline \multirow[t]{2}{*}{ acr3U } & 756 & $\begin{array}{l}\text { F: } \\
\text { ATCGATAAGCTTGATATCGAATTCCTGCAGGATGGATTTCGTGTTCACCGTC }\end{array}$ & Pstl & 71.4 \\
\hline & & R: CAGGGCTCGCGGCGAGCCTCTTTTGGCGATCC & & 74.3 \\
\hline \multirow[t]{2}{*}{ acr3D } & 986 & F: GAGGCTCGCCGCGAGCCCTGGTTAAGCGGCTC & & 75.6 \\
\hline & & $\begin{array}{l}\text { R: } \\
\text { TCTAGAACTAGTGGATCCCCCGGGCTCGAGAACCTCAAGCACGAGTCCGGCG }\end{array}$ & Xhol & 78.5 \\
\hline \multirow[t]{2}{*}{$\operatorname{ars} B \mathrm{U}$} & 1016 & F: CGGGTACCCGGCCGGCGAAATCGCC & Kpnl & 72.0 \\
\hline & & R: CGCTCGAGCGAACAGCGCCGACACCGCC & Xhol & 74.2 \\
\hline \multirow[t]{2}{*}{$\operatorname{arsBD}$} & 1016 & F: CGCTGCAGGGCGCGCCGTGGCAGGTC & Pstl & 74.9 \\
\hline & & R: CGGAGCTCTCGTTGAACGCCTTGGCGACACTC & Sacl & 71.7 \\
\hline
\end{tabular}

\section{Figures}

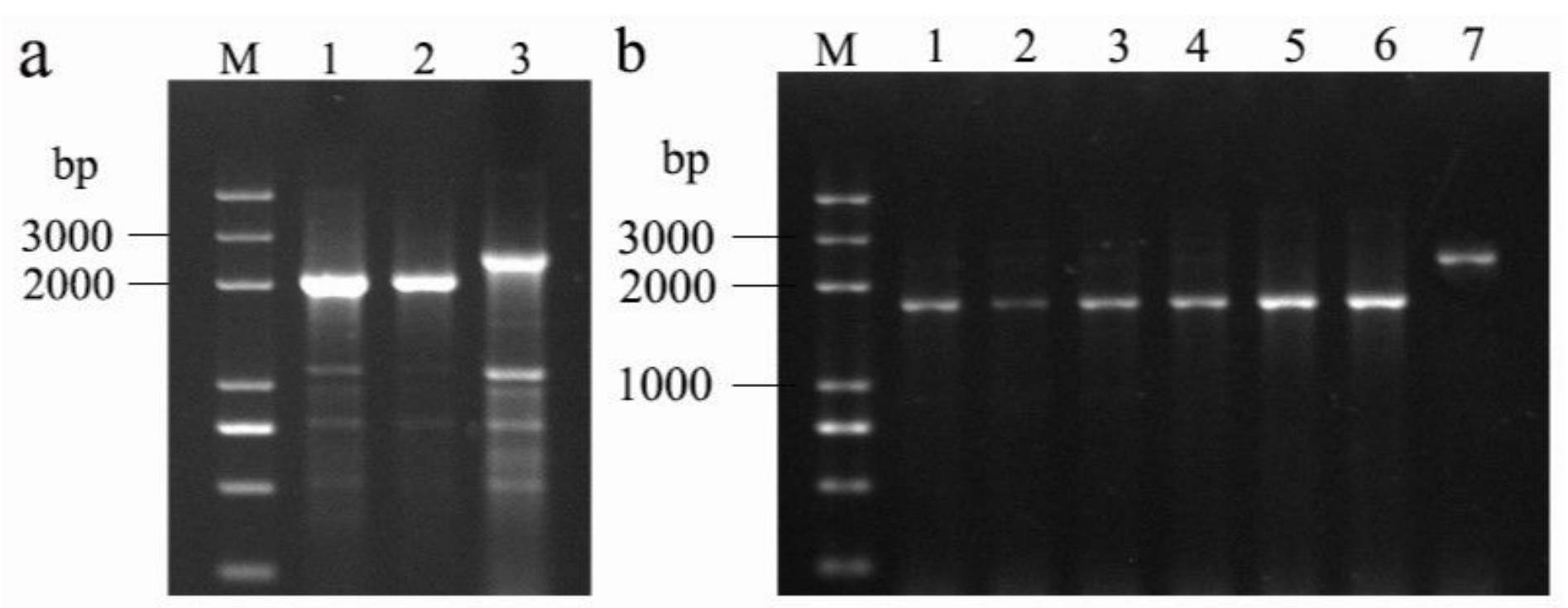

Figure 1

Identification of R. palustris CGA009 $\triangle$ arsB (a) and R. palustris CGA009 $\triangle$ acr3 mutants (b) by PCR. (a) Lane 1-2, R. palustris CGA009 $\Delta$ arsB (2000 bp); Lane 3, R. palustris CGA009 (2500 bp); (b) Lane 1-6, R. palustris CGA009 $\Delta$ acr3 (1742 bp); Lane 7, R. palustris CGA009 (2795 bp) ). Lane M, Trans2K® Plus DNA Marker 

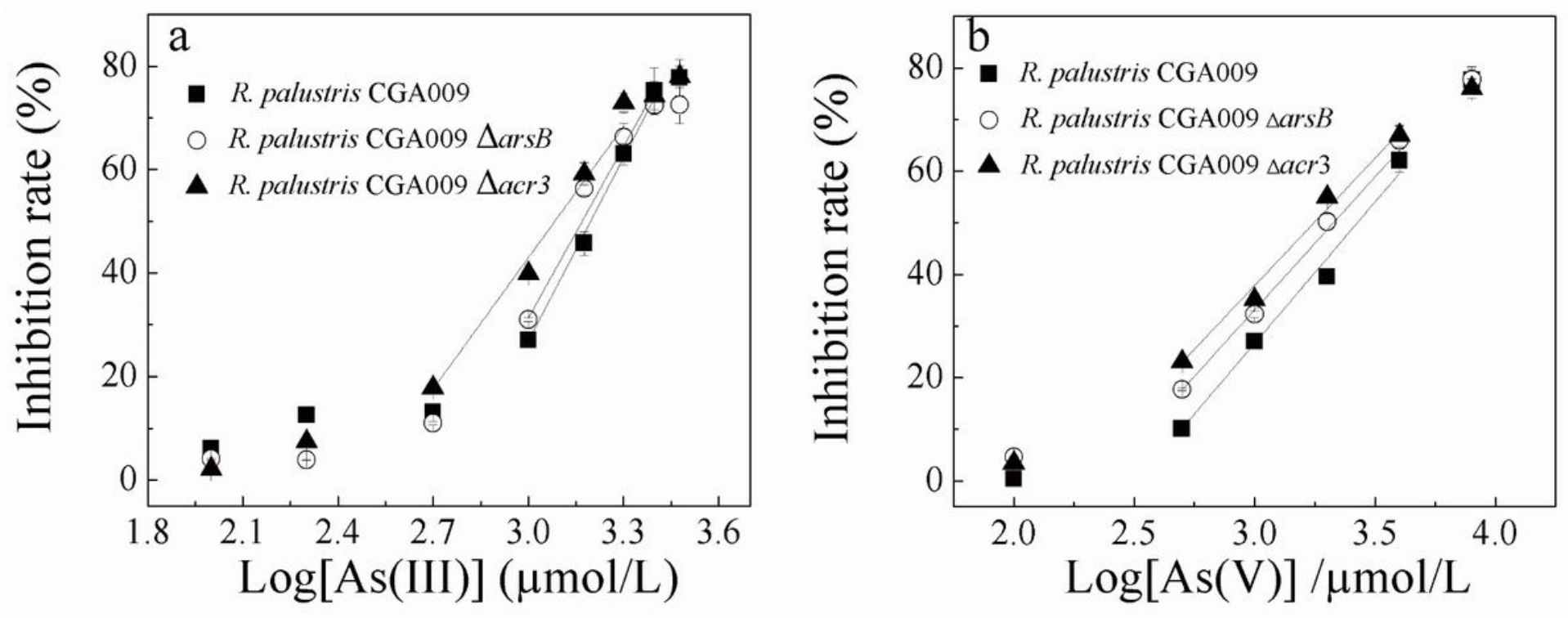

Figure 2

The effect of $\mathrm{As}(\mathrm{III})$ (a) and $\mathrm{As}(\mathrm{V})$ (b) on growth inhibition rate of the mutants. R. palustris CGA009 and its mutants were anaerobically grown at $300 \mathrm{C}$ with continuous illumination. Error bars indicate the standard deviation from three independent experiments 

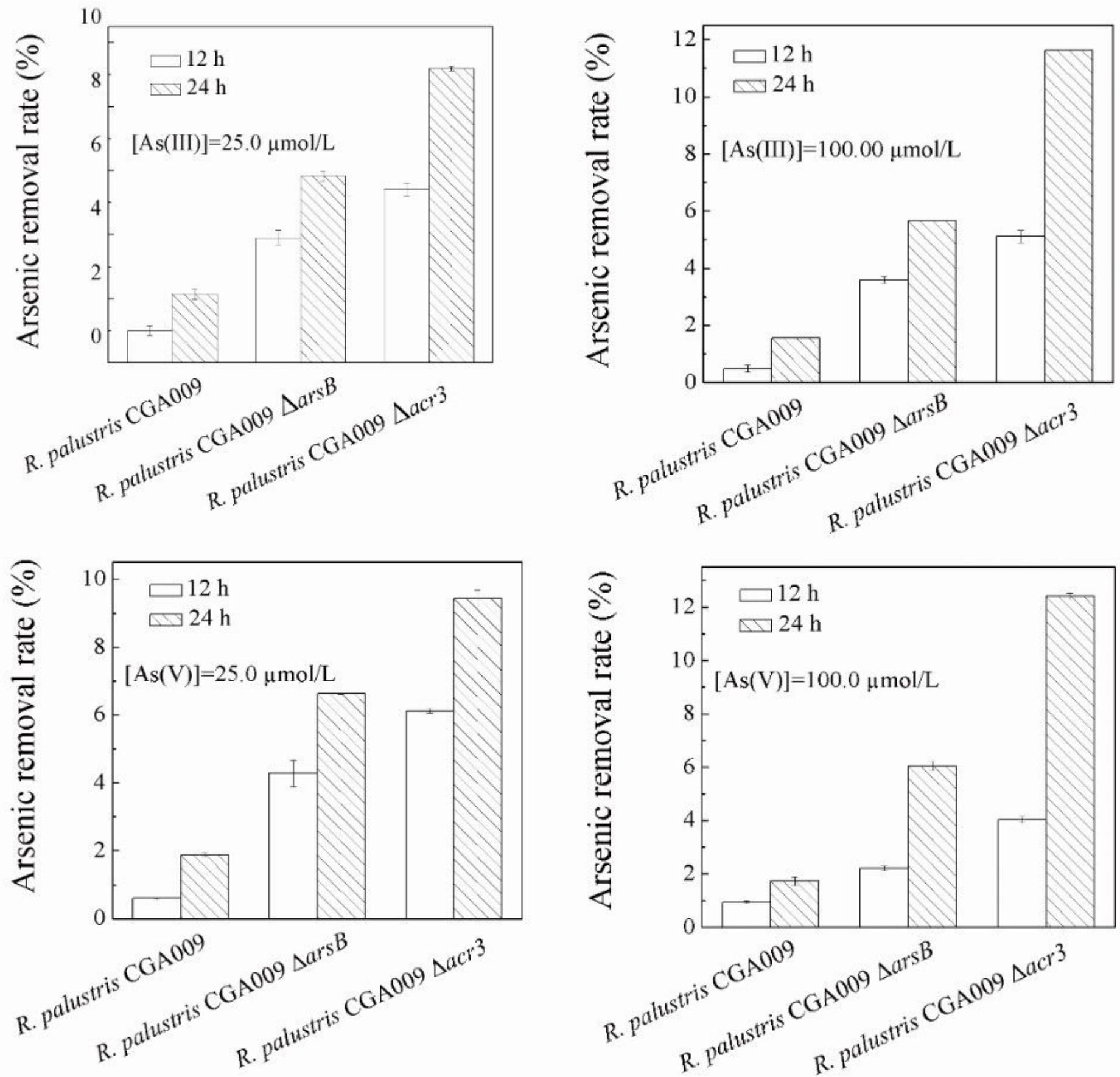

\section{Figure 3}

Comparison of As volatilization rate of the wild type R. palustris CGA009 and mutants. The mutant strain and wild type (OD660 about 0.4) was cultured in modified Ormerod medium containing 25.0 and $100.0 \mu \mathrm{mol} / \mathrm{L} \mathrm{As}$ (III) and $\mathrm{As}(\mathrm{V})$ at $30 \circ \mathrm{C}$ and with 2500 lux light for $12 \mathrm{~h}$ and $24 \mathrm{~h}$, respectively. Error bars indicate the standard deviation from three independent experiments 


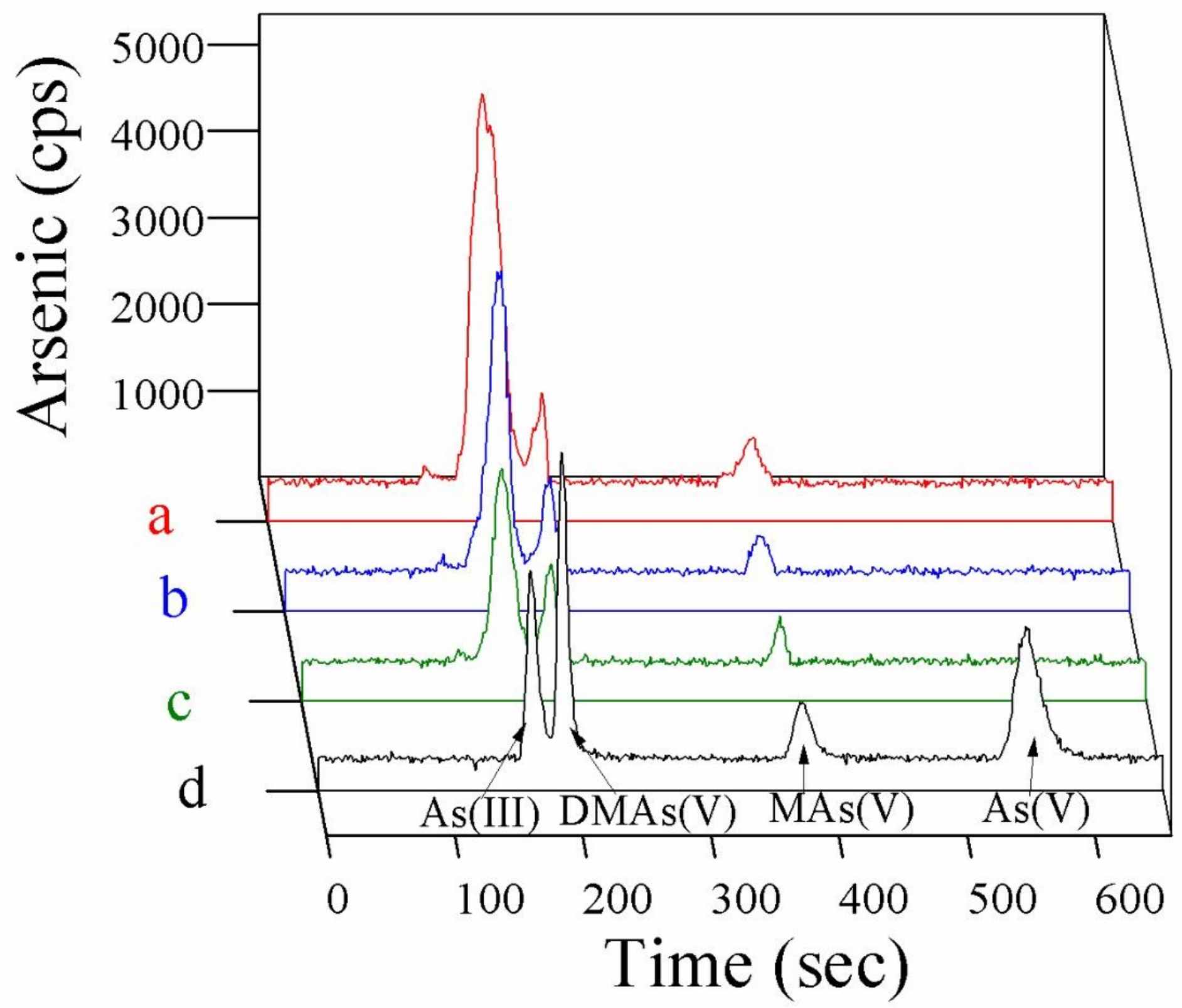

Figure 4

Arsenic speciation of the wild type and mutants determined by HPLC-ICP-MS. (a) R. palustris CGA009; (b) R. palustris CGA009 $\triangle$ arsB; (c) R. palustris CGA009 $\Delta$ acr3; (d) chromatogram of the standards, including As(III), $\operatorname{DMAs}(\mathrm{V}), \operatorname{MAs}(\mathrm{V})$ and As $(\mathrm{V})$, each of which has a concentration of $10 \mu \mathrm{g} / \mathrm{L}$. Speciation of As of the wild type and mutants grown on $25.0 \mu \mathrm{mol} / \mathrm{L} \mathrm{As}(\mathrm{III})$ for $24 \mathrm{~h}$

\section{Supplementary Files}

This is a list of supplementary files associated with this preprint. Click to download.

- SupplementalMaterials.docx 